For citation: Gokova O. V., Kiseleva A. M. (2017). Comparative Social and Economic Study of Youth Pro-Natalist Policy in the Regions of Germany, France and Russia. Ekonomika regiona [Economy of Region], 13(2), pp. 537-549 doi $10.17059 / 2017-2-18$

UDC: $314.04+330.341$

O. V. Gokova, A. M. Kiseleva

Dostoevsky Omsk State University (Omsk, Russian Federation; e-mail: capri484@yandex.ru)

\title{
COMPARATIVE SOCIAL AND ECONOMIC STUDY OF YOUTH PRO-NATALIST POLICY IN THE REGIONS OF GERMANY, FRANCE AND RUSSIA ${ }^{1}$
}

This article analyzes the results of three empirical studies conducted in Russia, Germany and France, which reveal value orientations of contemporary young people of these countries, the nature of their social behavior in the demographic context, as well as economic factors influencing it. The objectives of the study are the need to identify and systematize the factors that influence the reproductive behavior of today's youth from typical regions of these countries, as well as the evaluation of the experience of the organization and implementation of the pro-natalist policy accumulated by these three states. In the process of the questionnaire survey of young people in three countries, we formed an information database for the comparative analysis of young respondents' views on the issues of identifying their behaviour and value orientations in family life. We also use materials of the state statistics of these countries and the secondary analysis of the materials of sociological studies. On the basis of the conducted research and experience of implementation of pro-natalist policy in Germany and France, we have developed a number of measures of the Russian youth pro-natalist policy. The development of the labor market has a strong influence on the formation of the family value system of today's youth in Germany, France and Russia. It specifies the need to achieve a balance between creating a family, birth of children and the desire to create oneself as a professional. The possibility of achieving such life harmony must be ensured and supported by government measures in the framework of the effective pro-natalist policy.

Keywords: youth, youth pro-natalist policy, social and economic factors, reproductive behavior of today's youth, family values, demographic policy of Germany, France and Russia, the state system of support for young families with children, labor market and the family value system of today's youth, work-life balance

\section{Introduction}

Russia, in spite of the improvement of the demographic situation in recent years, is still in the demographic crisis, which, according to many researchers, may increase in the future. The modern demographic policy of the Russian state is mainly limited to measures of the economic nature; it does not eliminate the main cause of the demographic crisis, and therefore, may have only partial and temporary nature. At present, Russian authorities implement measures aimed at stimulating fertility. Nevertheless, we should notice that these measures are not very effective because of the following reasons: insufficient research and understanding of the factors influencing the development of the reproductive activity of population; the lack of regional differentiation of these measures, understanding of their linkages with regional social and economic policy; implementation of the averaged approach to the stimulation of fertility for different groups of population.

\footnotetext{
${ }^{1}$ ๑ Gokova O. V., Kiseleva A. M. Text. 2017.
}

Meeting these challenges involves systematization and consideration of all conditions connected with ensuring proper quality of life of the population and development of a certain demographic trend, in other words, pro-natalist policy, the formation of which should begin with regional level for a coherent solution of the demographic crisis within the whole country.

To understand the place and the role of pro-natalist policy in the system of demographic and family policies, the authors have revealed that pro-natalist policy is a sub-type of populationists policy, which, in turn, is one of the types of demographic policy. Unlike demographic policy, it does not include measures aimed at reducing mortality, increasing life expectancy and other aspects of population dynamics, apart from increasing fertility. The category of family policy, which includes a range of measures aimed at strengthening, developing and protecting the family institution as a fundamental basis of society, preserving and restoring traditional family values as well as increasing the social role of the family in society, is broader than the concept of pro-natalist policy. 


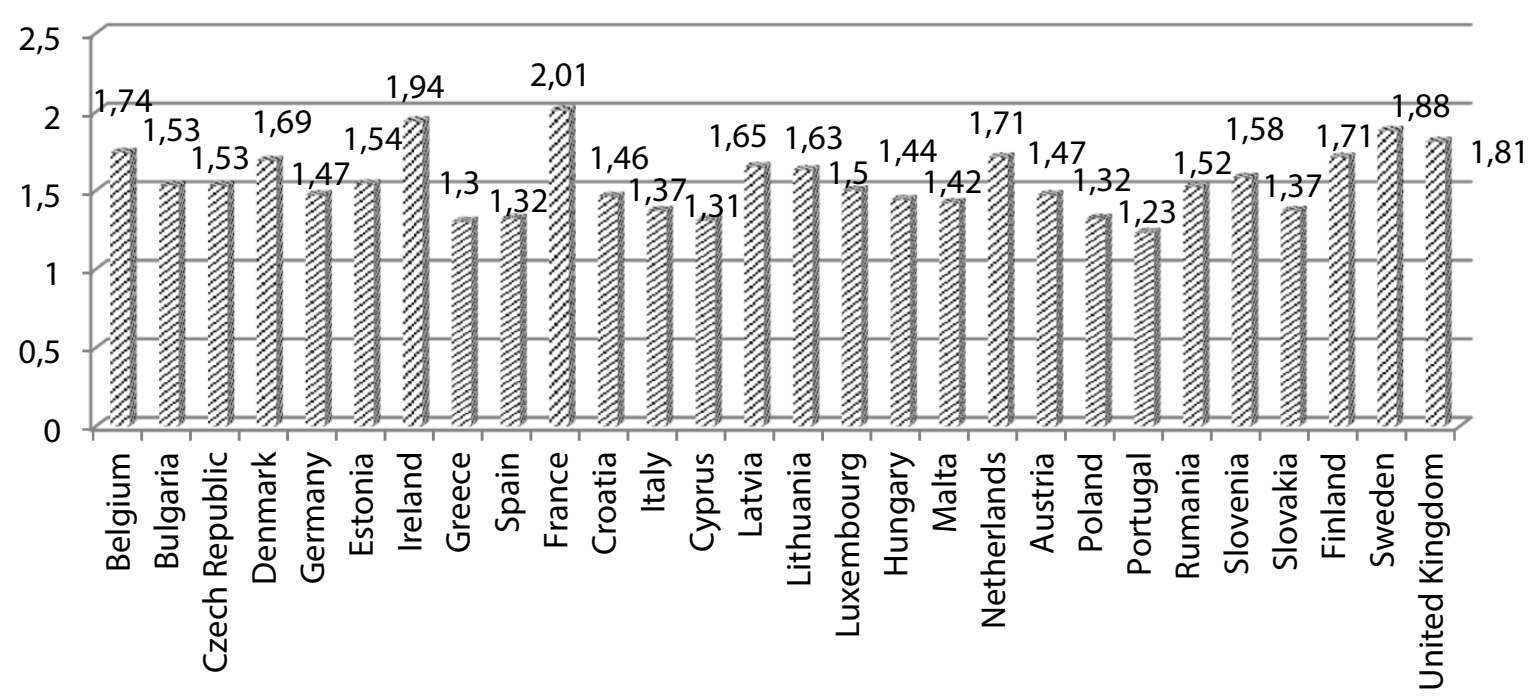

Fig. 1. Total fertility rate in countries of European Community in 2014 (Total fertility rate, 1960-2014. (live births per woman) (2016). Source: Eurostat. Retrieved from: http://ec.europa.eu/eurostat/statistics-explained/index.php/File:Total_fertility_ rate,_1960\%E2\%80\%932014_(live_births_per_woman)_YB16.png (date of access: October, 22, 2016))

Pro-natalist policy, on the one hand, is connected with demographic policy through interventions aimed at increasing one of the components of natural population change - fertility; on the other hand, it is closely related to family policy. The second aspect is caused by the unity of interests of family and pro-natalist policies expressed in increasing the number of births and, consequently, in formation of egalitarian relationships between spouses in the family; improving the situation of single-parent families; protecting families from the negative impact of changes related to economy, migration, urbanization, environment, so that the family often loses its ability to perform its functions; enabling the families to make competent decisions about the number, spacing and timing of their children. This has allowed the authors of the article to formulate a definition of pro-natalist policy, which they understand as the direction of populationists demographic policy, which represents a set of measures carried out by the state and municipal authorities and aimed at increasing the population and reducing the natural population loss by increasing the birth rate.

Demographic and, especially, the pro-natalist policy must take into account the specificities of different socio-demographic groups of the population; otherwise, it will simply have extremely low efficiency. Special attention should be paid to young people as the key player of pro-natalist policy and consumer of public services in the demographic sphere. Young people are the main resource for natural, migration and social reproduction of the population. From the demographic point of view, the youth have the primary re- sponsibility connected with reproductive behavior, namely: the creation of family, birth and upbringing of children. This social group is mostly affected by both economic factors (lack of material security, lack of housing and the need to help their parents), as well as moral and spiritual factors (vulnerability to negative trends of our time, leveling of family values, work values, increasing consumer attitude to the world) [1]. Hence, on the one hand, young people represent less socially protected a group which needs state support; on the other hand, the youth are generation upon which the demographic future of the country depends. Of course, the special status of the youth must be taken into account when determining the appropriate pro-natalist policy that can solve or mitigate the existing problems.

It is worth noting that Russia is not the only state in which depopulation trend increases (figure 1). Almost all developed European countries are now at the stage of «second demographic transition», which is characterized by a higher level of the population welfare, a high degree of involvement of women in social production, increase of their social role, increase the value of higher education and, as a result, decline of fertility and transformation of social attitudes towards family behavior [2, pp. 7-8].

In light of this, there is a need for a comparative study of factors which affect the change of reproductive behavior of young people from different countries, the attitude of young people towards the institution of marriage, illegitimate births and measures of the demographic (pro-natalist) policy. In our study, we have compared such countries as Russia, Germany and France as these coun- 


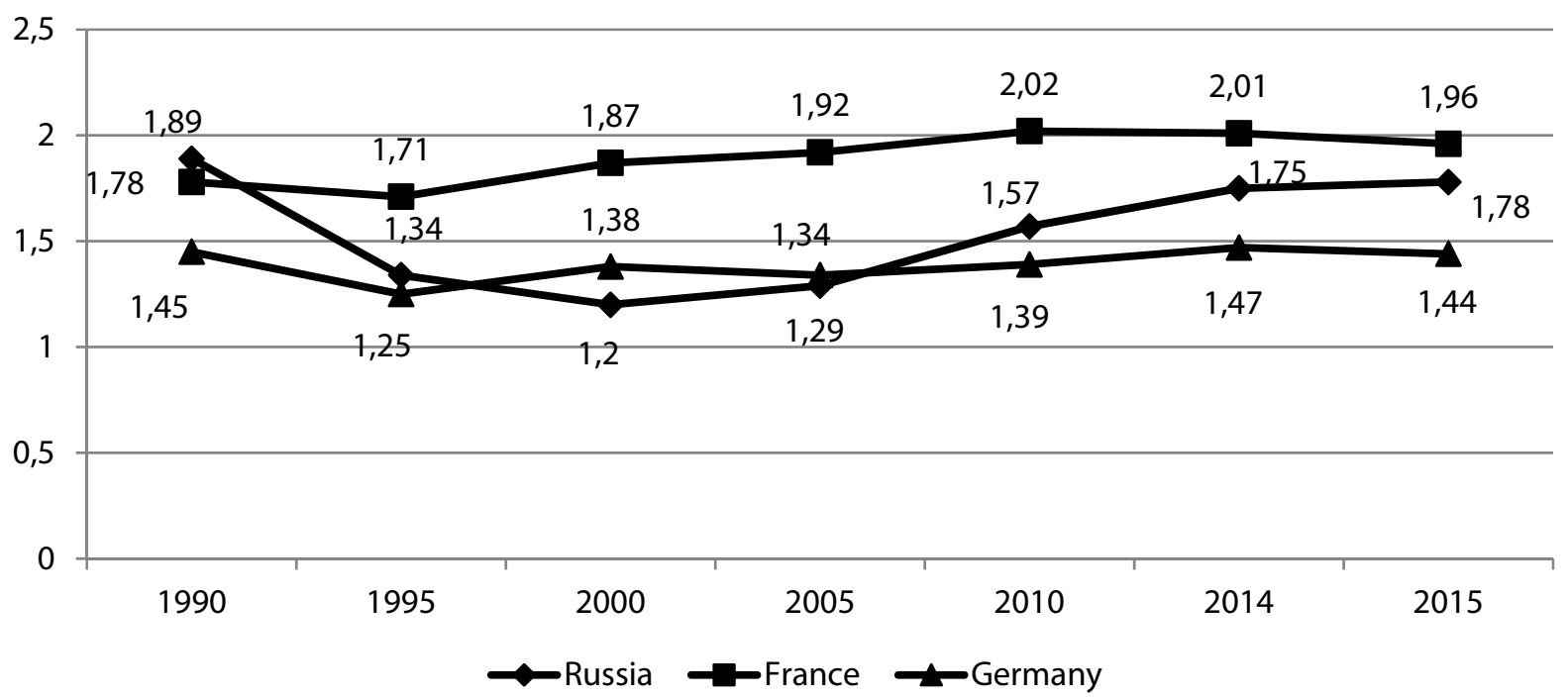

Fig. 2. Total fertility rates in Russia, France and Germany (1990-2015) (Taux de fécondité. (2016). Source: OCDE. Retrieved from: https://data.oecd.org/fr/pop/taux-de-fecondite.htm (date of access: October, 22, 2016))

tries have similar conceptual views on the issues of demographic processes' management (figure 2): Russia and Germany have common tendencies of demographic development, France is a country which has been conducting active pro-natalist policy since the end of the XIX century.

France was the first country in the world which started to implement measures aimed at increasing the birth rate, marriage rate and the increase in natural population growth. This country also gave the name to this type of public policy. These processes were historically caused by the demographic situation in the country at that time. At the end of the XIX century-early XX century, a sharp decline in natural population growth began in France. Despite the steady decline in mortality, the rate of fertility decline was higher: for the period from 1914 to 1919 the population of the country decreased by 3 million people, from 1939 to 1945 this figure was 1.2 million people. In 1946, France implemented in practice a system of cash payments and tax breaks for families. This practice was aimed at promoting the birth of the first, the second and especially the third child. As a result, by the mid-1980s among western European countries, France had one of the highest total fertility rates: the average number of children per woman was 1.8-1.9. The population increased annually by $0.3-0.4 \%$. Modern pro-natalist policy in France is a combination of different public measures and institutions aimed primarily at improving the well-being of families with children. Today to help young families (under 35 years) there are a lot of measures in the country. They include 15 different types of benefits (most of them do not depend on family income) as well as tax benefits and the duration of maternity leave which also increase with the size of the family.

The analysis of the experience of pro-natalist policy in Germany is caused by the similarity of demographic trends with Russia (especially in the eastern part of Germany). Germany is a country that did not dare to implement an active state demographic policy aimed at increasing the birth rate for a long time. It was caused by the historical features of the development of Germany, namely by its Nazi past. So, the country chose the so-called «second demographic transition path». Since 2002, the state began an active implementation of pro-natalist policy. During this time, in Germany, a generation of young people who appreciated personal freedom and independence, and put their interests above the interests of others and society as a whole, was formed. The study identified characteristics and changes in the minds of young people, in their way of life, value orientations as well as in spreading the philosophy of individualism and consumerism.

The experience of these countries is very important and interesting for the analysis and development of a set of measures of the youth pro-natalist policy in Russia. On the one hand, in the Russian practice, we can use a very successful form of support for young families, implemented in the above-mentioned countries; on the other hand, it allows to identify the problems which France and Germany faced (and still face), having passed the main stages of the «second demographic transition» long before Russia. It will help us to minimize their errors.

The main scientific idea of this study is the authors' approach to the formation of the mechanism of conducting the youth pro-natalist pol- 
icy in the regions of Russia, taking into account the experience of developed European countries (Germany, France) and various regional factors that influence reproductive behavior of young people. The study is comprehensive; it fell along two paths, which allowed us to draw attention to the indicated problems and make relevant proposals for the development of pro-natalist policy measures in the youth environment.

\section{Data and Methods}

\section{The First Research Task}

The first research task was defined by the need to identify and systematize the factors that influence reproductive behavior of today's youth from typical regions of France, Germany and Russia. To do this, we conducted three surveys in some regions of the Russian Federation, France and Germany in the period from July to October 2015. The purpose of the surveys was to study reproductive attitudes and attitudes of young people (aged from 20 to 35) to the institution of marriage. As for the Russian territories, we chose Omsk and Novosibirsk regions and the Khabarovsk territory as typical areas from the perspective of general trends of demographic development, the size and composition of the population, quantitative and qualitative characteristics of young people (in particular, the proportion of young people in these regions was at least $30 \%$ of the total population). In France and Germany, the survey was also conducted in those three regions, which showed the most common trends of the demographic behavior of today's French and German youth, and the share of young people in these regions was more than $30 \%$ of the total population. These regions were: Ile-de-France, Languedoc-Roussillon and Rhône-Alpes in France; Berlin, RhinelandPalatinate and Baden-Württemberg in Germany. The total number of respondents was 1136 people, including 616 young people who were interviewed in Russia, 286 people -in France and 234 respondents - in Germany. The average age of respondents was 26 years.

The results of our study have shown that $38 \%$ out of all young people interviewed in Russia are married; this figure in France is $33 \%$ and in Germany $-29 \%$ respectively. At the same time, it should be noted that $41 \%$ of respondents in France, $38 \%$ of young people in Germany and $21 \%$ of young couples in Russia live together without marriage (common-law partners).

We also have obtained an interesting data while studying how young people of different countries perceive the category of «family». Thus,
$97 \%$ of Russian respondents associate the concept of family with a married couple (a man and a woman), living together and having children. In France, $71 \%$ of respondents think that the family is a couple living within an unregistered marriage or a guest marriage with children, while $18 \%$ of French people state that the family, in their opinion, is also a household of two women or two men living with their children in a registered marriage. For $68 \%$ of young people surveyed in Germany, the family is living together of three generations of the family-grandparents, parents and children, but about $20 \%$ of the German youth believe that the family is a married couple without children. Curiously, $8 \%$ of respondents in France and $12 \%$ in Germany perceive the family as two women or two men living as a married couple without children. At present, Russian young people do not perceive such family model.

The question «How many children are you planning to have?» was answered in the following way: $11 \%$ of respondents (125 people) said they did not want to have children in the future $(66 \%$ out of this figure (83 people) live in Germany, $21 \%$ (26 people) live in France and $13 \%$ (16 people) live in Russia). Germany shows a very low birth rate. It is proved not only by empirical data of our study, but also by the data of the Federal Statistical Office where it is stated that the total fertility rate in Germany in 2014 amounted to 1.47 births per woman. France and Germany also show a relatively late and increasing age of the first childbearing - 30-33 years. In Russia, this age is lower, but the decisions connected with creating a family and the birth of a child are often shelved since the late 1980s.

Respondents mentioned the problems that contributed to lowering the age of childbirth in young families. Thus, the vast majority of respondents from Russia think that the two main reasons for postponing the birth of a child to a later date are «the lack of their own homes»-39\% (240 people) and «insecurity in the future» $-18 \%$ (111 people). In France, the majority of young people indicate that «the desire to live for themselves for some time» (34\% or 97 people) and «studies» (17\% or 49 people) are sufficient reasons that prevent young couples from having children. $37 \%$ of German young people think that «the desire to make a career» is the main reason for postponing or even complete abandonment of the idea of having a child. $21 \%$ of German respondents say that «studies» is another important reason which has a significant deterrent effect on the process of creating a family and having children. In addition, $7 \%$ of German people give their own answers. 
They point out that the most important reasons for postponing the birth of a child are the desire to maintain their independence, the ability to travel and the lack of desire to take responsibility for the child.

One should also note that the desire to have children depends greatly on the country of the respondents' residence. In Russia, 51 \% of respondents say that an ideal family is a family with two children, whereas in France only $34 \%$ of respondents supported a family model with two children; $38 \%$ of the French consider a family with three children being «ideal». In Germany $31 \%$ of respondents indicate that they would like to have one child in the family, $27 \%$ of respondents want to have two children and only $6 \%$ are eager to have three or more children.

The development of the labour market and the increase of female employment may be a more important factor influencing the birth rate than the special family policy measures in this regard. In France, the income of a mother has a much greater impact on the planning process of childbirth than the income of her partner [3]. In Germany and Russia, on the contrary, a partner's income has a greater impact on the planning of having the second and third child.

Thus, the development of the labour market has a strong influence on the formation of the system of family values of today's youth in Germany, France and Russia, specifying the need to achieve some balance between creating a family, birth of children and the desire to form oneself as a professional. The possibility of achieving such life harmony must be ensured and protected by the state measures through the effective demographic (pro-natalist) policy.

\section{The Second Research Task and the Results}

The second objective of the study is an evaluation of three states, accumulated experience of organization and implementation of pro-natalist policy to the population. This intensive analysis in combination with an examination of the factors influencing reproductive behavior of the youth, will allow us to develop a number of practical steps for the Russian pro-natalist policy, which will help to support and protect the interests of young families.

\subsection{Family Policy in Germany}

Family policy in Germany is somewhat paradoxical in terms of its openness and readiness to the modern changes in family and marriage relations and, at the same time, in the need to preserve «traditional» family values, in particu- lar when dealing with childcare and marriage. Currently, Germany has accepted and is developing a fairly large number of non-traditional forms of family relationships. For example, registration of same-sex partnerships is possible. Children, who are brought up by single parents and parents, who are not married, have no social stigma: they have the same rights as children born in officially registered marriage.

Today, Germany can be characterized from two different angles: in the Western lands, it is a conservative state of general welfare, while in the Eastern lands, there remained mentality, characteristic for the socialist system. From 1949 to 1989 , the state policy aimed at increasing the fertility rate in Eastern and Western Germany had significant differences [4, pp. 3-4]. In the Eastern lands, the family model with two working parents was dominant and was supported by the state. In Western Germany, the government promoted and supported the traditional family model with a man as a breadwinner and traditional division of labour between a husband and a wife. However, to avoid the analogy with Nazi Germany, West German politicians avoided using the term «pro-natalist policy». Based on the principle of «sustainable family policy», which was first introduced in 2002, the German government has been gradually trying to increase fertility and reduce child poverty by creating conditions for a possible reconciliation of work and family life for women ${ }^{1}$.

Since 1996, the right to a place in a kindergarten for children from the age of three and before entering school has been guaranteed in Germany. Since 2013, this programme has been expanded. Now it includes children from one year. Childcare is carried out mostly by private non-profit organizations, organizations of the Protestant and Catholic churches, as well as municipal authorities. Moreover, to make such children's institutions, organized by civil society organizations, as well as family-type nursery schools are more popular; the state provides them with subsidies and other forms of support. Although preschool fees in these institutions are not approved by the Federal law, payments from parents are charged according to the size of the family income. Since 2006, working parents can receive a tax deduction for the payment of attendance of preschools by their children [5].

\footnotetext{
${ }^{1}$ Germany: A modern family policy for more partnership when it comes to creating a work-family balance and economically stable families. (2015). European Union: European Platform for Investing in Children. Retrieved from: http://europa.eu/epic/ countries/germany/index_en.htm (date of access: April, 25, 2016).
} 
In comparison with other countries, the cost of education in kindergartens in Germany is quite low, as the parent contribution for kindergarten is set by the municipalities, taking into account significant regional differences. In some lands, children's attendance of pre-school education institutions one year before school entry is free. In the Rhineland-Palatinate region, children from the age of two can attend children's leisure centers for free. Herewith, more than $90 \%$ of children aged from three to five attend pre-school institutions in Germany, but in most cases, it is part-time attendance. According to statistics, in 2014, about $75 \%$ of children spent less than 6 hours a day in kindergartens ${ }^{1}$.

In both parts of Germany, the first form of child care leave, introduced in 1970, was an extended maternity leave (up to one year). In 1986, in the GDR and in the FRG, a form of maternity leave, which can be taken by both a mother and a father of the child, was introduced. A new «Swedish» model of child care leave was introduced in Germany in 2007. Now parents can be on maternity leave with a child up to three years. Until the child reaches 14 weeks one parent, who is on maternity leave, receives compensation from his/her employer in the amount of a full salary. This measure is aimed at attracting fathers to participate in childcare. Since the introduction of these rules, the proportion of fathers who use paternity leave has been increasing steadily from $21 \%$ for children born in 2008 to $29 \%$ for children born in $2014.78 \%$ of fathers, who had paternity leave for children born in 2014, were on leave for about two months. As a rule, working parents receive a monthly allowance in the amount of $67 \%$ of their average monthly income during 12 months after the child's birth. Wherein, a monthly allowance paid by the state, shall not exceed 1,800 euros. If the income of the family member is below 1000 euros per month, he/she receives an allowance from $67 \%$ to $100 \%$ of his/her previous average monthly income. After some budget cuts in 2011, the allowance was reduced for parents with average individual income above 1,200 euros a month, but not less than $65 \%$ of their previous average monthly income. Unemployed parents receive a monthly al-

\footnotetext{
1 Daten zum Demografischen Wandel in Deutschland: Bevölkerungsentwicklung und -struktur, Geburten, Lebenserwartung und Pflege. (2013). Bundesministerium für Familie, Senioren, Frauen und Jugend. Retrieved from: http:// www.bmfsfj.de/RedaktionBMFSFJ/Abteilung3/Pdf-Anlagen/ daten-zum-demografischen-wandel-praesentation,property $=$ pdf,bereich $=$ bmfsf, , sprache $=$ de, $r w b=$ true.pdf $($ date of ac cess: May, 27, 2016).
}

lowance from the government amounting to 300 euros per child ${ }^{2}$.

Maternity protection has a long tradition in Germany. Since 1878 employers were forbidden to employ women in the first three weeks after the birth of a child. Since 1883 mandatory health insurance was introduced and an allowance for all the period of maternity leave in the amount of half of the average wage was established. In modern practice, maternity leave for working women is 6 weeks before giving a birth and 8 weeks after the birth of a child. The maternity leave is additionally extended by 4 weeks in case of premature or multiple births. At present, women receive a monthly allowance of $100 \%$ of their average monthly income for 14 weeks, which is paid by the state in accordance with the requirement of obligatory medical insurance.

According to the labour legislation of Germany, women cannot be dismissed during pregnancy and the first 4 months after the birth of a child. In addition, any employed parent with a child under the age of 12 is entitled to take ten days of a paid leave to care for a sick child (the maximum is 25 days per year for each child) [5].

Currently, in Germany, there is a mixed system of child allowances and tax benefits, which redistributes resources from childless people to families with children and from families with high incomes to families with low incomes. Child allowances are almost universal and are paid for each child monthly based on the number of children in the family. In 2015 this sum was equal $€ 184$ for the first and second child,190 euros for the third child and 215 euros for the fourth and subsequent children. The allowance is usually paid until the child reaches 18 years of age or until 25 years if the child receives full-time education. The tax authorities upon audit of annual tax declarations submitted by parents have the right to give them additional tax relieves apart from child allowance payments. Parents with annual family income below 63000 euros (or single parents with an annual income below 33500 euros) may be entitled to additional tax benefits. Single parents can have an additional tax deduction in the amount of 1308 euros per child ${ }^{3}$.

\footnotetext{
${ }^{2}$ Germany: A modern family policy for more partnership when it comes to creating a work-family balance and economically stable families. (2015). European Union: European Platform for Investing in Children. Retrieved from: http://europa.eu/epic/ countries/germany/index_en.htm (date of access: April, 25, 2016).

${ }^{3}$ Kindergeldauszahlung 2016-Auszahlungstermine. (2016). Kindergeld.org. Retrieved from: http://www.kindergeld.org/ kindergeldauszahlung.html (date of access: June, 7, 2016).
} 
In 2015 , in order to increase the involvement of parents in working life and facilitate the sharing of family responsibilities within the family, the Federal government of Germany introduced a new parental allowance («Elterngeld Plus») and a bonus for the preservation of marriage and family («Partnerschaft Bonus»), which was applied to children born after July 1, 2015. In the early years of a child's life, a difficult task for parents is the need to combine work and childcare. The new program allows parents working part-time to extend the period of parental allowance for two months after the birth of a child. Mothers and fathers can choose an option when they can both work parttime (for up to four months from 25 to 30 hours per week) and receive monthly supplementary child allowance ${ }^{1}$.

Thus, a difficult demographic situation makes the German government respond flexibly to the needs of young families. At present, German politicians are interested in the qualitative improvement of the demographic situation due to the growth in the indigenous German population. Therefore, they care about stable perspectives for the young generation of the Germans, the increase in the number of permanent jobs with strong social guarantees, as well as the creation of additional places in kindergartens [6, p. 98]. The German youth, especially with a higher education degree, are not ready to become parents at the expense of their professional development and social status, because thoroughness typical for the German mentality makes them think about the future of their unborn children. In this case, it does not matter how much the state pays for a child, as parental allowances will not replace stable prospects of regular labour relations for young people [7, pp. 560-561]. According to the polling data, in Germany $63 \%$ of young people have expectations of the government with regard to measures that will facilitate the opportunity to combine a professional job with creating families and raising children.

\subsection{Pro-natalist Policy in France}

In France, the birth rate has traditionally always been at the centre of political attention, so pro-natalist policy in France has a long history and is aimed at providing a large number of different measures in the form of benefits, tax concessions and direct funding of attendance preschools for children, as well as free primary and second-

\footnotetext{
${ }^{1}$ Elterngeld Plus: die neue Generation Vereinbarkeit. (2016). Bundesministerium für Familie, Senioren, Frauen und Jugend. Retrieved from: http://www.elterngeld-plus.de/ (date of access: June, 7, 2016).
}

ary school education. Compared with other countries of the Organization for economic cooperation and development (OECD) the amount of state funds allocated to assist families with children is quite high ${ }^{2}$.

Pro-natalist development policy in France has passed four main stages:

1) up to 1970s: the state developed the model of a family with a man as a bread-winner. In such families, men worked and women took care of children and home. These measures included providing families with children with tax deductions (from 1946 to 1972);

2 ) in the 1970s and 1980s: policy gradually began to focus on assistance to working women in combining career and family. Allowances for childcare for working mothers were introduced. Since 1980, a system of public preschool education evolved. In 1985, the state allowance for women with three or more children, who left work and devoted themselves to raising children, was introduced. At that time, France was the only country in Europe that provided such allowance, aimed exclusively at aid and increasing the number of large families;

3) in the 1990s: this period is characterized by the development of the policy of expanding the range of children care services by means state subsidies for pre-school institutions. Working parents, who used babysitting services at home or in private family kindergartens, received an allowance that covered these expenses. Payment of care services for children could be also compensated by receiving tax deductions. In addition, since 1994 the child support grant has been extended to mothers with two children, and since 2004-for mothers with one child (but it is paid only for six months) [8, pp. 42-44];

4) since the mid-2000s - up to the present: pro-natalist policy is increasingly using a differentiated approach to support based on different needs of families. The main measures include the following:

- development of the system which gives the opportunity to adopt flexible working hours for working parents;

- opening of special centers of medical and social assistance, as well as providing assistance to families with children with disabilities or serious illnesses;

- assistance to low-income families and children from low-income families (espe-

\footnotetext{
${ }^{2}$ Family Policies: France. (2014). Population Europe Resource Finder \& Archive. Retrieved from: http://www.perfar.eu/policy/ family-children/france (date of access: June, 15, 2016).
} 
cially children from poor families and/or migrant families). It is one of the priority directions of the policy. Children from socially-disadvantaged families are entitled to free places in kindergartens;

- formation of a network of providers who offer a wide range of services for families with children, ranging from private persons (home services) to collective centres. Various authorities, from municipalities to the government of France, control availability and quality of these services. Specific reforms of the structure of control for diversification of services are undertaken. They include: stimulating the development of services for parents with non-standard flexible work schedule, facilitating access to services for poor and/or migrant families, provision of services for children with disabilities or serious illnesses, provision of babysitting services at home [9, pp. 17-19].

Currently, there are two directions of pro-natalist policy in France: a traditional direction, which contributes to the preservation of family values and is focused on one working parent in the family - a man; and a feminist direction, whose followers support individualization of social rights of women and their participation in the labor sphere [10].

According to French experts, one of the main factors of the growth of fertility rate in the country is a developed system of childcare $[11$, p. 16 ; 12]. In France, availability of childcare services for children up to 3 years is $48 \%$. It is considered that this level is insufficient. In comparison, on average in OECD countries this figure is $31 \%$, while in Russia it is only $16 \%$. In 2009, the French Government set a goal to create 200 thousand places for children up to 3 years in municipal nurseries or nurseries at home over four years. At the moment, this goal has been achieved by $80-90 \%$, which is a very good result. The system of care services for children under 3 years has a great diversity of forms. These include:-collective nurseries, providing services from 8 to 16 hours;-departmental nurseries at enterprises or nurseries created for employees' children in terms of cooperation between enterprises (they are completely adapted to the work schedule of parents); - family nurseries (kindergarten teachers, who are hired by a specialized agency, work there. The agency pays them a salary and takes the children. In this case, the state (not parents) pays the agency for childcare.);-certified nannies who watch a child or a small group of children at their own home; - nannies who watch a child or a small group of children at parents' home. Expanding choices of forms of childcare is an attempt to meet the needs of all parents ${ }^{1}$.

In this case, the provision of childcare services is not a government jurisdiction. Municipal or departmental nurseries get money directly, while certified nannies are paid by parents who receive necessary public assistance. Families declare costs and send them to the regional family allowance office-Caisse d'allocations familiales (CAF), where the amount of payments for the family is calculated [13].

Thus, French experience shows that systematic and long-lasting pro-natalist policy can be demographically effective and lead to sustainable growth in the birth rate to the level of simple reproduction of the population and above. The basis of successful policy is a sufficient level of expenditure for its implementation (at least 4-6\% of GDP) and the joint participation of government, business and civil society in the national system of support for families with children, implemented through the institutions of family policy.

\subsection{The Demographic Policy in Russia}

In Russia, the demographic situation has significantly improved for the last 8 years. Statistical data about the increase of birth rate in Russia from 1610,1 thousand births in 2007 (the beginning of the implementation of the pro-natalist policy reforms) to 1942,7 thousand births in 2015 (the increase was 1.2 times), prove $i^{2}$. The increase of fertility rate in Russia in recent years has been mostly affected by: general rise in the standard of living of the population (pre-crisis situation); encouraging the birth of the second (third) child through introduction of a new form of state financial support in the form of the parent capital on the Federal and regional levels; active promotion of family values among the youth.

However, most experts believe that this improvement of the demographic situation has no long-term prospects due to some reasons. The first group of reasons includes: complicated financial and economic conditions, low solvency of the population, including the situation in the real estate market, insufficient number of free places in kindergartens, poor free medical care. All these do not encourage young women to have a child.

\footnotetext{
${ }^{1}$ The French Social Security System. Family Benefits. (2016). CLEISS. Au service de la protection sociale à l'international. Retrieved from: http://www.cleiss.fr/docs/regimes/regime_ france/an_4.html (date of access: June, 18, 2016).

${ }^{2}$ Fertility, mortality and natural increase from 1950 till 2014. (2015). Federal State Statistics Service. Retrieved from: http:// www.gks.ru/wps/wcm/connect/rosstat_main/rosstat/ru/ statistics/population/demography/\# (date of access: June, 20, 2016).
} 
The second group of reasons is based on the statistic data which show that the dynamics of demographic indicators has an undulating character: recession periods alternate with periods of growth. This dynamics is explained by changes in differences in numbers between generations, including women of childbearing age and the ratio of men and women of childbearing age. And thirdly, we should distinguish negative impact on the processes of fertility of such factor as confidence in the future, which is of multidimensional nature and additionally includes psychological aspect and stability of the political situation. Hence, the need to maintain the achieved level of natural population growth in the long term arises $[14, \mathrm{pp}$. $1-2 ; 15$, pp. 210-211; 1].

Currently, young mothers in Russia can receive a few types of the state social benefits on the birth of a child, which are envisaged by the law of the Russian Federation in the sphere of social support of families. They are: a one-time payment in respect of a child's birth, «maternity capital» (the birth of the second and subsequent children) ${ }^{1}$, a monthly allowance for child care. A lump-sum benefit is paid to a woman regardless of whether she works or is unemployed. The size of a one-time payment in respect of a child's birth is 14497,8 rubles (approximately 171 euros according to the exchange rate in February 2016). In addition, a woman has the right to receive a monthly childcare allowance until the child reaches the age of eighteen months. Non-working mothers can obtain this allowance through the bodies of social protection directly from the month of the child's birth. In this case, the allowance will be in a fixed minimum amount of 2,718.34 rubles (32 euros) for the first child and 5436,67 roubles (64 euros) for second and subsequent children. For working women, a monthly allowance for the child up to eighteen months is calculated in the accounting department of the organization where a woman worked before her maternity leave. Since 2011, a new rule in the calculation of this allowance was introduced: calendar days that fall during periods of temporary disability, maternity leave and child care leave, as well as leave from work with full pay (if the premiums were not charged) are excluded

\footnotetext{
${ }^{1}$ Federalnyy zakon Rossiyskoy Federatsii ot 29 dekabrya 2006 g. № 256-FZ (pocl. obn. 30 dekabrya, 2015 g.) “O dopolniteknykh merakh gosudarstvennoy podderzhki semey, imeyushchikh detey" [Federal Law of the Russian Federation dated December 29, 2006, No. 256-FZ (last updated December 30, 2015) «On additional measures of state support of the families which have children»]. (2015). Legal Reference System «KonsultantPlus». Retrieved from: https://www.consultant.ru/document/cons_ doc_LAW_64872/ (date of access: June, 21, 2016). (In Russ.)
}

from the settlement period. When calculating the amount of the allowance for child care average income is divided by the number of calendar days for two years (730 or 731 days, if one year falls on a leap year $)^{2}$.

Furthermore, a number of regional allowances, the size of which depends on the budgetary provision of each region, shall be paid at the birth of a child. A lump-sum benefit and a monthly allowance are paid to wives of military personnel performing compulsory military service $(10,528.24$ rubles (124 euros) and 24,565.89 rubles (289 euros), respectively, for each child ${ }^{3}$.

We also should mention compensation from the authorities for failing to provide places in kindergartens and electronic queues to kindergarten. The issue of compensation for parents (or their legal representatives) for failure to provide a place in a kindergarten is not regulated at the federal level, however, the decision to pay compensation for the lack of places in kindergartens are taken at regional level. In some regions of Russia (Kirov region, Perm region, Krasnoyarsk territory, Smolensk oblast, Khanty-Mansi and YamaloNenets Autonomous Okrug, Tomsk region, etc.) this allowance is already paid. Its value depends on several factors: the age of a child, average family income and number of children. The compensation is paid to all families, regardless of whether a young mother works or not. As a rule, the average compensation ranges from 2000 to 5000 roubles (from 24 to 60 euros) and is subject to annual indexation. Since 2016, the individual income tax is levied from the sum returned to parents.

Since 2013, in the Russian Federation, there is an electronic queue to kindergartens which is available at a portal of public services of the Russian Federation (www.gosuslugi.ru). An electronic queue allows people to: submit electronic applications for admission of children into kindergartens or the change of a kindergarten; carry out an automatic check of information in electronic statements through interaction with the registrar's office; inform citizens via text messages and sending letters by e-mail; notify parents about the availability of places in preschool educational institutions. This public service can significantly speed up and simplify the procedure for admission of a child into a kindergarten.

\footnotetext{
2 Family Benefits and Maternity Benefits in 2016. (2016). Retrieved from: http://subsidii.net/ (date of access: June, 22, 2016). (In Russ.)

${ }^{3}$ Family Benefits and Maternity Benefits in 2016. (2016). Retrieved from: http://subsidii.net/ (date of access: June, 22, 2016). (In Russ.)
} 
In Russia, standard tax deductions for both parents may be claimed for dependent children. It means that income tax at the rate of $13 \%$ is deducted from a certain amount of the parents' income. Tax deduction for children from 2016 is provided until the month in which the taxpayer's income, taxable at the rate of $13 \%$ and calculated on an accrual basis since the start of the year, has exceeded 350 thousand roubles (4217 euros) ${ }^{1}$.

Working women in Russia are entitled to 70 calendar days of maternity leave before childbirth and 70 calendar days after childbirth. During this period, social insurance benefits at the average earnings amount are paid. Pregnancy and family benefit is paid to young working women, female students, women officers, fired women in connection with the liquidation of the organization and registered as unemployed jobseekers with a TE office. At the same time, non-working women do not receive pregnancy and family benefit. From 1 January 2011, the payment of this benefit is made on the basis of the average daily earnings for 2 calendar years preceding the year when a woman takes maternity leave. Payment is made by the employer at the expense of the state organization - the social insurance fund.

Since the end of maternity leave, a young mother or a father (from 2009 the procedure of taking maternity leave for employee-fathers was simplified), who takes care of the child, may take child care leave. During this type of leave, the allowance of $40 \%$ of average earnings at the expense of the social insurance fund is paid to a parent until the child reaches 18 months. After maternity leave, one of the parents (as well as any child's relative - a grandmother, an aunt, etc. if they wish so), takes childcare leave until a child reaches the age of 3 . The job of this person is kept open during this time ${ }^{2}$.

Due to the current difficult financial and economic situation in Russia and the need for a targeted approach to the provision of measures of social assistance in view of limited budgetary resources, there are two opinions about the necessity of the state participation in the implementation of pro-natalist policy. On the one hand, given that the basic principle of distribution of social welfare in the state is universalism, all citizens, including young families, have the right to social

\footnotetext{
${ }^{1}$ Standartnyye nalogovyye vychety [Standard Tax Deductions]. (2016). Kontur.accounting. Retrieved from: http://www.b-kontur.ru/enquiry/258 (date of access: June, 22, 2016). (In Russ.)

${ }^{2}$ Posobie na rebenka [Maternity Benefit]. (2016). Rashchet dekretnykh vyplat [All about child benefits]. Retrieved from: http://posobie-expert.ru/po-beremennosti/dekretnoe-posobie/ razmer-dekretnyx/ (date of access: June, 22, 2016). (In Russ.)
}

security and social services implemented through the state budget. On the other hand, the individual principle should dominate in the state, which involves the personal responsibility of young people for the fate of their family [16, p. 1095]. This principle assumes a direct dependence of the size of insurance premiums and the amount of the state social services received from the state. The state takes responsibility for maintaining only a minimum income of all citizens and the welfare of the most vulnerable people.

\section{Results and Conclusion}

Based on the conducted research and the experience of implementation of pro-natalist policy in Germany and in France, we have developed a set of measures of the Russian youth pro-natalist policy for the regional level.

First, we think that one of the most important measures of pro-natalist policy should be a modification of the terms of maternity leave. According to our research, the most important factor influencing the postponement or even rejection of having children is the unwillingness of the majority of women (including Russian women) not to participate in social and professional life, in connection with the birth and upbringing of a child, for a long time. Being on maternity leave for two-three years often makes a woman uncompetitive in the labour market as she loses professional skills.

Many Russian women, who are fully immersed in the upbringing of children, do not participate in any social life: they either have no time or mental attitude. The development of the labour market and the employment opportunities of women may be a very important factor influencing a higher birth rate than special family and demographic measures applied in this regard. Policy, which contains measures to ensure accessibility to employment for young women, their continued employment and sufficient income is a certain precondition for women to make a decision regarding having the first or another child. A long period of maternity leave and gender-segregation policy give women the message that combining work with motherhood, return to the labour market after maternity leave and maintaining the same level of life, can be quite difficult. This leads to fertility reduction. Wider provision of child care services, high level of cash maternity benefits, the possibility of providing flexible maternity leave, as well as policy, focused on gender equality, can reduce concerns of young women about the impossibility of combining career and child care and help them to make an easier decision about family planning. 
Our proposal involves providing several options for the system of maternity leave and allowances depending on the wishes of parents:

a) four months' maternity leave with keeping a job and $100 \%$ of salary. After that, a young woman can go to work and use the services of a certified nanny who watches a child at her own home or at the child's home. For example, in France there is a system of specially trained child care providers who watch children at their own homes: there are about 300 thousand of nannies caring for more than 1 million children, i.e. on average, one child care provider looks after three children. Today, these home nurseries are the most common and available form of care for young children. In Russia, depending on the level of budget sufficiency of the region the cost of babysitting services can be offset by the regional budget, both federal and regional budgets or young parents based on their financial capabilities;

b) maternity/paternity leave divided between two young parents: the first part of parental leave is taken by a mother (3.5 months), then she goes to work, and the second part is taken by a father (up to 3.5 months); parents' jobs are kept open during their leaves and average monthly wage remains unchanged. After the leave parents can return to work; use babysitting services (as in the first option), send a child to a kindergarten or extend partially paid parental leave to care for a child (with continued employment), which can last until the child reaches 3 years old.

Secondly, the current model of preschool education in Russia is designed mainly for children aged from 3 to 7 years. We suppose it should be supplemented by a variative system of care for children up to 3 years and support for employment of young women. In fact, the area of social care and childcare should be introduced in the education system. Allowance for child care, which should be paid in case of receiving childcare service in accredited care centers (nurseries, kindergartens) or from certified nurses, should be a financial instrument. For the creation and development of this system, one can use the material and educational base of existing pre-school educational institutions. Funds of commercial enterprises, increased excise taxes on tobacco and alcohol, taxes on gambling business - and their target use for the financing of family policy measures - may become additional financial sources for the development of such system. As the nursery system in Russia is being created almost from scratch, the development of a Concept of development of the system of childcare services for children up to 3 years both at the fed- eral and regional levels is required. The Concept should take into account: the possibility of opening nurseries at business enterprises for their junior staff; involvement of private business in the creation of this system; promoting the exchange of experience between specialists from different countries in this field.

Thirdly, another measure of the youth pro-natalist policy should be the establishment of a culture of «work-life balance» (maintaining the balance between work and personal life). The orientation of the youth on family creation on the basis of labor compatibility, birth and upbringing of children is good both for young families and for society as a whole. This policy may include a variety of options: many young mothers would like to participate in professional development more actively, while fathers can spend more time with their children and receive child allowance. Children will see their parents more often. Such combination of work and personal life is one of the key moments of the contemporary youth pro-natalist policy. In addition, this system may include providing flexible working hours with part-time work to both parents or to one parent.

Fourthly, the creation of a supportive environment, which includes a large number of devices and daily practices, facilitates the life of a young family. The use of a special child seat for a bike or a cargo bike with up to four children gives young mothers an opportunity to spend much time with children outside and maintain their physical form. The establishment of special children's rooms in the large shopping, entertainment and medical centers, wheelchair ramps, parking lots for bicycles - all this will allow young women with children to feel full-fledged members of society, eliminate discomfort and restrictions in connection with the birth of a child. The Russian media should broadcast the idea that the birth of a child does not affect a dynamic lifestyle of young parents and the participation of young mothers in a social life. Numerous examples in France, Germany, the United States, the Scandinavian countries prove that having children does not significantly alter the possibility of participation of young women in ordinary daily life. In these countries, young mothers with children go to restaurants, exhibitions, conferences, lectures and perceive it as «self-evident».

Fifth, as the results of opinion polls show the housing problem is the main problem for young families in Russia. In this case, it is advisable to develop a system of preferential mortgage loans for young families, including the lowering of interest rates in credit depending on the number 
of children (the more children a person has, the lower the interest rate is). Preferential provision of land for construction of homes would also help to solve the housing problem of young families. A number of Russian experts in the sphere of demographic policy note that one of the possible variants of solving the housing problem of young people is reimbursement (usually partial) of rental housing payment. When children are born to a family, reimbursement of costs should be made (usually when a family has got two or more children). In addition, we can offer such measure of the youth pro-natalist policy as the construction of social housing and low cost of credit resources attracted for the acquisition of property.

Thus, an important condition for the effectiveness of the Russian youth pro-natalist policy is a systematic combination of various options for the implementation of social and economic policy in relation to families with children: direct state support, tax incentives, development of the necessary infrastructure. The modern demographic situation in Russia and the need to maintain the achieved progress require the development of new solutions and using the best international practices (including the experience of France and Germany).

\section{References}

1. Sinelnikov, A. B. (2010). Transformatsiya semeynykh otnosheniy I ee znazhenie dlya demograficheskoy politiki Rossii [Transformation of the family relations and its value for population policy in Russia]. Semya rastet: pro semyu i dlya semyi [The family grows: about a family and for a family]. Retrieved from: http://www.semya-rastet.ru/razd/transformacija_semejjnykh_otnoshenijj_i_ejo_znachenie_dlja_demograficheskojj_politiki_v_rossii/ (date of access: April, 5, 2016). (In Russ.)

2. Lesthaeghe, R. (2010). The Unfolding Story of the Second Demographic Transition. Conference on «Fertility in the History of the 20th Century - Trends, Theories, Public Discourses, and Policies» (Halle, Germany, January 21-23, 2010). Halle: Population Studies Center, 46.

3. Zagorez, W. \& Zagorez, I. (2014). Demograficheskaya politika: metody I instrumentariy, opyt primeneniya i analiz effektivnosti [[Demographic Policy: Methods and Instruments, Application Experience and the Analysis of Effectiveness]. Zhurnal mezhdunarodnogo prava i mezhdunarodnykh otnosheniy [Journal of International Law and International Relations], 2. Retrieved from: http://www.evolutio.info/content/view/2257/235/ (date of access: June, 27, 2016). (In Russ.)

4. Ostner, I., Reif, M. \& Turba, H. (2012). Family Policies in Germany. Third report for the project «Welfare Policies and Employment in the Context of Family Change» (Utrecht, Netherlands, October 8-9, 2012). Utrecht: Institute of Social Policy Georg-August-University, 25.

5. Schwesig, M. (2014). Familienreport-2014: Leistungen, Wirkungen, Trends. Bundesministerium für Familie, Senioren, Frauen und Jugend. Retrieved from: http://www.bmfsfj.de/RedaktionBMFSFJ/Broschuerenstelle/Pdf-Anlagen/ Familienreport_202014,property=pdf,bereich=bmfsfj,sprache=de,rwb=true.pdf (date of access: May, 27, 2016).

6. Büchel, F. \& Spiess, K. (2012). Kindertageseinrichtungen und Müttererwerbsarbeit-Neue Ergebnisse zu einem bekannten Zusammenhang. Vierteljahreshefte für Wirtschaftsforschung, 71(1), 95-113.

7. Dorbritz, J. (2008). Germany: Family diversity with low actual and desired fertility. Demographic Research, 19, 557598. doi: 10.4054/DemRes.2008.19.17.

8. Damon, J. (2006). Les Politiques Familiales. Presses Universitaires de France: P.U.F., 128.

9. Prokofyeva, L., Rybalzhenko, S. \& Yuryev, E. (2012). Semeyanaya politika Frantsii: vozmozhnosti primeneniya uspeshnogo opyta $v$ Rossii [French family policy: the possibility of applying a successful experience in Russia]. Moscow: Institute of Scientific-Social Expertise Publ., 48. (In Russ.)

10. Thévenon, O., Adema, W. \& Ali, N. (2014). Family policy in France and Europe: recent changes and effects of the crisis France. Population \& Societies INED 512. Retrieved from: https://www.ined.fr/fichier/s_rubrique/19853/population_societies_2014_512_family_policy_effects_crisis.en.pdf (date of access: June, 18, 2016).

11. Thévenon, O. (2008). Does Fertility Respond to Work and Family-life Reconciliation Policies in France? CESifo Conference on Fertility and Public Policy (Munich, Germany, February 1-2 2008). Munich: CESifo Group, 36.

12. Vanovermeir, S. (2012). Laccueil des jeunes enfants: axe majeur de la politique familiale française depuis les années 1970. Dossiers solidarité et santé 31. Retrieved from : http://drees.social-sante.gouv.fr/IMG/pdf/article31.pdf (date of access: June, 18, 2016).

13. Lépinard, E. \& Lieber, M. (2015). The Policy on Gender Equality in France. European Parliament. Retrieved from: http://www.europarl.europa.eu/RegData/etudes/IDAN/2015/510024/IPOL_IDA510024_EN.pdf (date of access: June, 18, 2016).

14. Frejka, T. \& Zakharov, S. (2012). Comprehensive Analyses of Fertility Trends in the Russian Federation during the Past Half Century. Working paper of Max Planck Institute for Demographic Research (WP-2012-027), 29.

15. Rimashevskaya, N. M. (2004). Sotsialno-ekonomicheskie I demograficheskie problemy sovremennoy Rossii [Socialeconomic and demographic problems in the context of today's Russia]. Vestnik Rossiyskoy Akademii Nauk [Herald of the Russian Academy of Sciences], 74(3), 209-218. (In Russ.)

16. Salles, A., Rossier, C. \& Brachet, S. (2010). Understanding the long term effects of family policies on fertility: The diffusion of different family models in France and Germany. Demographic Research, 22, 1057-1096. doi: 10.4054/ DemRes.2010.22.34. 


\section{Authors}

Olga Vladimirovna Gokova - Senior Lecturer, Chair of Regional Economy and Public Management, Department of Economics, Dostoevsky Omsk State University (1, Litskevicha Sq., Omsk, 644090, Russian Federation; e-mail: capri484@ yandex.ru).

Albina Musaevna Kiseleva - Doctor of Sociological Science, Professor, Chair of Regional Economy and Public Management, Department of Economics, Dostoevsky Omsk State University (1, Litskevicha Sq., Omsk, 644090, Russian Federation; e-mail: albkis@mail.ru). 